\title{
Effects of drip irrigation on canopy and soil temperature, leaf gas exchange, flowering and nut setting of mature coconut (Cocos nucifera L.)
}

\author{
A. Nainanayake ${ }^{1 *}$, C. S. Ranasinghe ${ }^{1}$ and N. A. Tennakoon ${ }^{2}$ \\ 1 Plant Physiology Division, Coconut Research Institute, Lunuwila. \\ 2 Soils and Plant Nutrition Division, Coconut Research Institute, Lunuwila.
}

\begin{abstract}
Coconut (Cocos nucifera L.) yield is greatly influenced by environmental factors with rainfall playing a major role in replenishing the soil moisture reservoir within the root zone. Soil water deficits reduce transpiration from the palm, leading to an increase in canopy temperature which in turn could reduce photosynthesis and yield. The primary objective of this study was to investigate the effects of drip irrigation on temperature changes in the canopy microclimate, leaf gas exchange, flowering and nut setting of mature coconut palms. Three water regimes were imposed on 20 year old coconut palms and the above-mentioned parameters were observed over a period of two years.
\end{abstract}

Results showed that irrigation lowered the temperature of the canopy microclimate and the nut surface temperature, and thereby reduced the possibility of empty nut formation during dry spells. Further, irrigation reduced stomatal resistance and thereby probably nullified the effects of drought on photosynthesis. Irrigation increased the female flower production and reduced immature nut fall during droughts, thus improving the yield. Application of 80 litres of water per palm per day lowered the canopy temperature more than 40 litres of water and significantly improved female flower production and nut setting.

Keywords: Canopy temperature, coconut, irrigation, soil temperature, yield

\section{INTRODUCTION}

The coconut palm has concurrent vegetative and reproductive phases and its productivity is substantially influenced by environmental variables ${ }^{1}$. Rainfall has been identified as a factor with a significant influence on the monthly variation of coconut yield in Sri Lanka². Depletion of soil moisture due to drought is the main cause for triggering physiological and biochemical changes within the coconut palm, leading to a reduction in nut yield. In some coconut growing countries such as India, irrigation has been practiced in coconut plantations to improve the productivity ${ }^{3}$. In Sri Lanka, drip irrigation of coconut has shown promise for increasing productivity. However, very little research data is available on the performance of coconut palms under drip irrigation.

The tropical climatic conditions in Sri Lanka with high solar radiation generally increase transpiration and soil evaporation causing rapid depletion of soil moisture. As long as the root system of a palm is capable of increasing the rate of soil moisture absorption to compensate the transpirational water loss, stomatal regulation does not come in to effect. However, as soon as the rate of water loss exceeds that of water absorption the resulting water deficit triggers the regulation of transpiration at stomatal level. The reduction of stomatal conductance inevitably obstructs the gaseous and water vapour exchange through stomata leading to lowering of photosynthesis causing a reduction of yield. This also leads to a building up of heat in the leaf canopy, thus increasing the temperature which is detrimental if it increases above $40{ }^{\circ} \mathrm{C}$. High canopy and air temperatures under hot tropical weather during droughts could affect the process of photosynthesis, button nut development, fertilization, nut setting and final yield. The increase in soil temperature in the effective root zone during droughts may also disrupt the proper functioning of roots reducing their water absorption capacity. Irrigation with sufficient amounts of water during dry weather would definitely arrest these deleterious effects facilitating the photosynthetic process which could invariably lead 
to a better yield. Hence, the primary objective of this study was to evaluate the effects of drip irrigation on the canopy and soil temperature and nut setting in coconut plantations.

\section{METHODS AND MATERIALS}

The drip irrigation experiment was conducted at Ratmalagara Research Station ( $\left.\mathrm{IL}_{1}\right)$, Madampe, by the Soils and Plant Nutrition Division, Coconut Research Institute of Sri Lanka (CRISL). The experimental location had shallow (30 - $60 \mathrm{~cm}$ ) sandy clay loam soil (Andigama series) which belongs to the land suitability class $\mathrm{S}_{4}$ based on the soil classification introduced by Somasiri et al. ${ }^{4}$ The experimental design was a Randomized Complete Block Design (RCBD) with four replicates and five treatments. Each experimental plot had four palms approximately 20 years of age. All palms were planted at a spacing of 7.8 $\mathrm{m} \times 7.8 \mathrm{~m}$ in a square planting arrangement. The plots were managed as recommended by the CRISL. A sub soil drip line and screw drippers were established to provide water to coconut palms at different irrigation intervals. Although there were five different treatments, only three treatments (i.e. T1, Control, No irrigation; T2, Irrigation with 40 litres of water per palm per day; and T3, 80 litres of water per palm per day after a 14-day rain-free period) were selected for the present study. A preliminary experiment was conducted on the same soil to determine the best time to commence irrigation. The results showed that the soil moisture content reduced approximately to half of field capacity within a 14-day rain-free period. Three palms from each plot were used for the experiment.

The drip irrigation system used in the study has been in operation since November 2002 and the measurements were taken on all selected palms during both the wet and dry periods from May 2004 to March 2006. Measurements included air temperature of the canopy just above the $7^{\text {th }}$ (upper canopy) and just below the $10^{\text {th }}$ bunch of nuts (lower canopy). (The newly opened inflorescence was considered as the $1^{\text {st }}$ bunch and counting downwards) and temperature of the surface of topmost nuts $\left(\mathrm{T}_{\text {nut }}\right)$ of $7^{\text {th }}$ and $10^{\text {th }}$ bunch exposed to sunlight (Checktemp thermometer, Hanna Instruments, UK). Measurements were done twice during the day (from 10 a.m. to 12 noon and from 2 p.m. to 4 p.m.) Leaf stomatal diffusive resistance (of the $9^{\text {th }}$ leaf from top which is generally considered as the representative leaf for physiological measurements in coconut) was measured using a Steady State Porometer (Li- 1600, Li-Cor Inc., Nebraska, USA). Soil temperature $\left(T_{\text {soil }}\right)$ was recorded twice during each measurement day (7-10 a.m. and 1-3 p.m.) at the depth of $30 \mathrm{~cm}, 1 \mathrm{~m}$ away from the base of the palm. Similarly, air temperature $\left(\mathrm{T}_{\text {air }}\right)$ within the upper canopy (just above the $7^{\text {th }}$ bunch) and lower canopy (just below the $10^{\text {th }}$ bunch) were monitored twice a day. Numbers of female flowers and set nuts were also recorded on all bunches developed during the period until they were plucked as matured coconuts. Set nuts of the matured bunch just prior to the pick was considered as the final yield.

Rainfall data were obtained from the weather station maintained by the CRISL at the same estate. The mean soil moisture content within the top $150 \mathrm{~cm}(\theta, \%)$ was measured in parallel with other measurements using the gravimetric method. Soil core samples were collected at three different depths viz. $0.5 \mathrm{~m}, 1.0 \mathrm{~m}$ and $1.5 \mathrm{~m}, 1 \mathrm{~m}$ away from the base of the palm. Soil moisture cans were filled with complete cores of soil (approximately $200 \mathrm{~cm}^{3}$ ) from each depth and weighed immediately. They were then oven dried at $70{ }^{\circ} \mathrm{C}$ for $72 \mathrm{~h}$ in a fan forced oven and the dry weights were measured. Three replicates of soil core samples were taken for each treatment and the mean soil moisture content $(\theta)$ was calculated as the average of soil moisture content at the 3 depths. Analyses of variance (ANOVA) were done using Statistical Analysis System (SAS Release 8.2, USA).

\section{RESULTS}

\section{Rainfall and soil moisture}

Three dry spells viz. from July to September 2004 (48 days), December, 2004 to March, 2005 (78 days) and July to October, 2005 (83 days) were experienced during the experimental period (Figure 1). Rainfall was welldistributed during the rest of the experimental period with a substantially higher rainfall from September to November 2004 . Soil moisture content $(\theta, \%)$ of nonirrigated control plots reduced significantly during dry spells (Figure 2). The soil moisture content was reduced by about $58 \%$ in September 2005 compared to the highest $\theta(17.5 \%)$ observed during the experimental period (November, 2004). Mean $\theta$ of T2 and T3 plots during dry periods were $14 \%$ and $17 \%$ respectively.

\section{Impacts of irrigation on soil, nut surface and air temperatures}

Substantial increases in soil, nut surface and air temperatures were observed under all water regimes in the afternoon session ( 1 to 3 p.m.) of the day during both wet and dry periods (Figure 3 ). Significant differences were seen between the treatments during dry periods. Similarly, significant increases in diffusive resistance and decreases in transpiration rate were observed in the afternoon, especially under drought conditions 


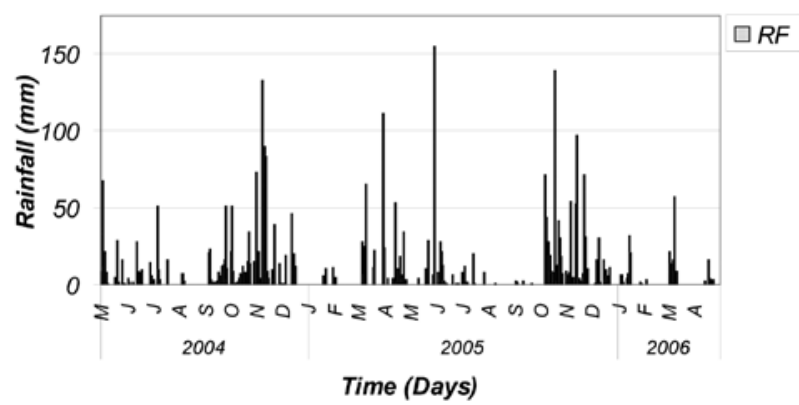

Figure 1: Daily rainfall (mm) at the experimental site during the experimental period (from May, 2004 to April, 2006).

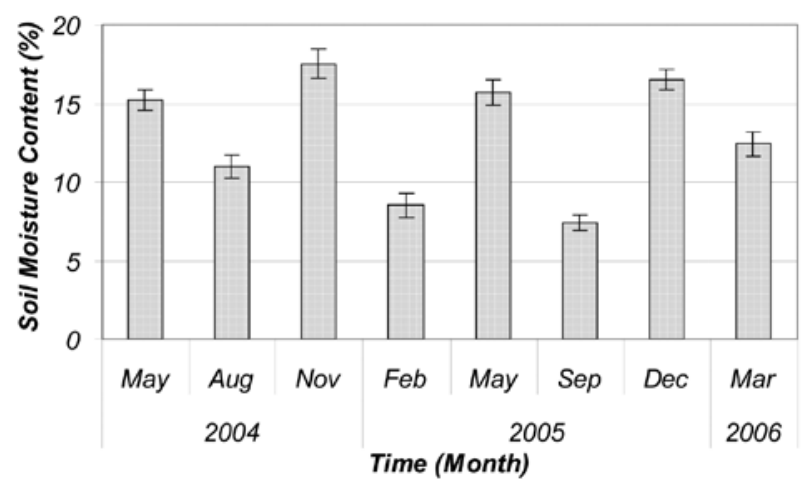

Figure 2: Mean soil moisture content $(\theta, \%)$ within the top $150 \mathrm{~cm}$ of the soil in non irrigated plots on each measurement day during the experimental period. (Vertical bars indicate the SE of the mean)
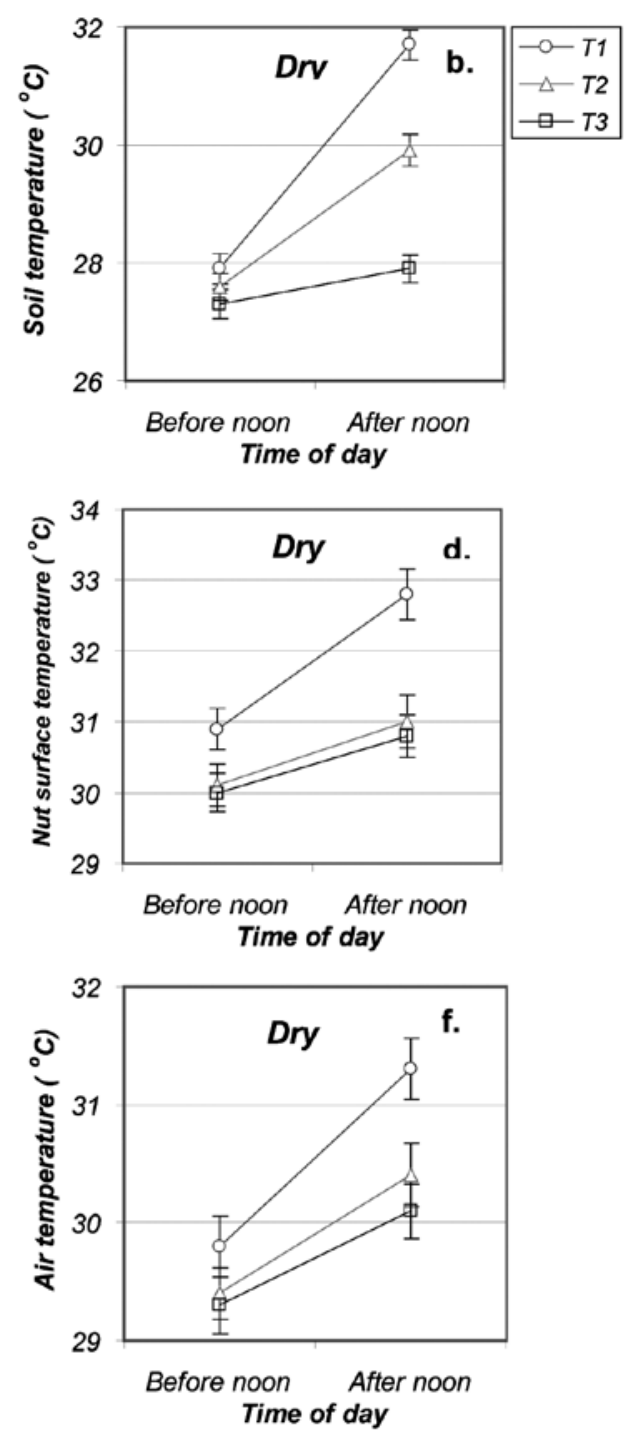

Figure 3: Temperature $\left({ }^{\circ} \mathrm{C}\right)$ of soil $(\mathrm{a} \& \mathrm{~b})$, nut surface of $7^{\text {th }}$ bunch $(\mathrm{c} \& \mathrm{~d})$ air surrounding the $7^{\text {th }}$ bunch (e \& f) during wet and dry periods. (T1 - Control [No irrigation], T2 - 40 L/Palm/Day, T3 - 80 L/Palm/Day) 
(Figure 4). Therefore, temperature parameters and gas exchange parameters obtained in the afternoon were used for comparison of the effects of different water regimes.

No significant differences were observed in soil temperature $\left(\mathrm{T}_{\text {soil }}\right)$ among treatments under wet weather conditions during the experimental period (Figure 5a). However, $\mathrm{T}_{\text {soil }}$ increased by $4{ }^{\circ} \mathrm{C}$ in non irrigated control plots as compared to $\mathrm{T} 3$ plots irrigated at $80 \mathrm{~L} / \mathrm{palm} /$ day during the three dry spells experienced. Although the $\mathrm{T}_{\text {soil }}$ of T2 plots which were irrigated with $40 \mathrm{~L} / \mathrm{palm} /$ day increased above that of $\mathrm{T} 3$, still the maximum increase of $1.5{ }^{\circ} \mathrm{C}$ was less than that observed in $\mathrm{T} 1$. Therefore, drip irrigation at both rates was effective in reducing soil temperature below that of the non irrigated control during dry periods.

There were no significant differences in nut surface temperature $\left(\mathrm{T}_{\text {nut }}\right)$ of the $7^{\text {th }}$ bunch between different water regimes during wet periods ( $\mathrm{X}=30.0^{\circ} \mathrm{C}$ ) (Figure $5 \mathrm{~b}$ ). Variation pattern of $\mathrm{T}_{\text {nut }}$ in the $10^{\text {th }}$ bunch was similar to that of the $7^{\text {th }}$ bunch (data not shown). However $T_{\text {nut }}$ increased by $2.5{ }^{\circ} \mathrm{C}$ in the control plots as compared to T3 plots (irrigation with $80 \mathrm{~L}$ per palm per day) during dry spells. $\mathrm{T}_{\text {nut }}$ in $\mathrm{T} 2$ plots (irrigation with $40 \mathrm{~L}$ per palm per day) also showed temperatures which were up to $1.5{ }^{\circ} \mathrm{C}$ lesser than those in control plots. Thus, drip irrigation had significantly reduced $(\mathrm{p}<0.01) \mathrm{T}_{\text {nut }}$ during dry spells.
Air temperature $\left(\mathrm{T}_{\text {air }}\right)$ within the canopy (both upper and lower parts) showed no significant difference between the water regimes (Figure 5c) under wet conditions. But $\mathrm{T}_{\text {air }}$ in $\mathrm{T} 3$ was significantly lower $(\mathrm{p}<0.05)$, by $>2{ }^{\circ} \mathrm{C}$, than that of the control during the drought in September 2005. Irrigation with $40 \mathrm{~L}$ per palm per day (T2) was also effective in lowering $\mathrm{T}_{\text {air }}$ by at least $1^{\circ} \mathrm{C}$ compared to that of the control. Changes of $\mathrm{T}_{\text {air }}$ in upper and lower parts of the canopy were not significantly different.

\section{Impact of irrigation on gas exchange}

The effects of irrigation on the transpiration rate $(E)$ and stomatal diffusive resistance $\left(\mathrm{r}_{\mathrm{s}}\right)$ was more marked than those on temperatures. No significant difference was observed in transpiration rate between water treatments during wet periods (Figure 6a). However, $E$ reduced by $55 \%, 70 \%$ and $95 \%$ respectively in control plots as compared to T3 plots during three consecutive droughts experienced during the experimental period. $E$ was almost unaffected by drought when palms were irrigated with $80 \mathrm{~L}$ per palm per day (T3). Even when palms were irrigated with $40 \mathrm{~L}$ per palm per day $E$ was reduced by $13 \%, 20 \%$ and $25 \%$ as compared to the irrigation with $80 \mathrm{~L}$ per palm per day. The $\mathrm{r}_{\mathrm{s}}$ increased 3, 4 and 6-folds in control plots during the three dry spells when compared to T3 plots (Figure $6 \mathrm{~b}$ ). In contrast, $r_{\mathrm{s}}$ of $\mathrm{T} 2$ increased only one fold when compared to T3
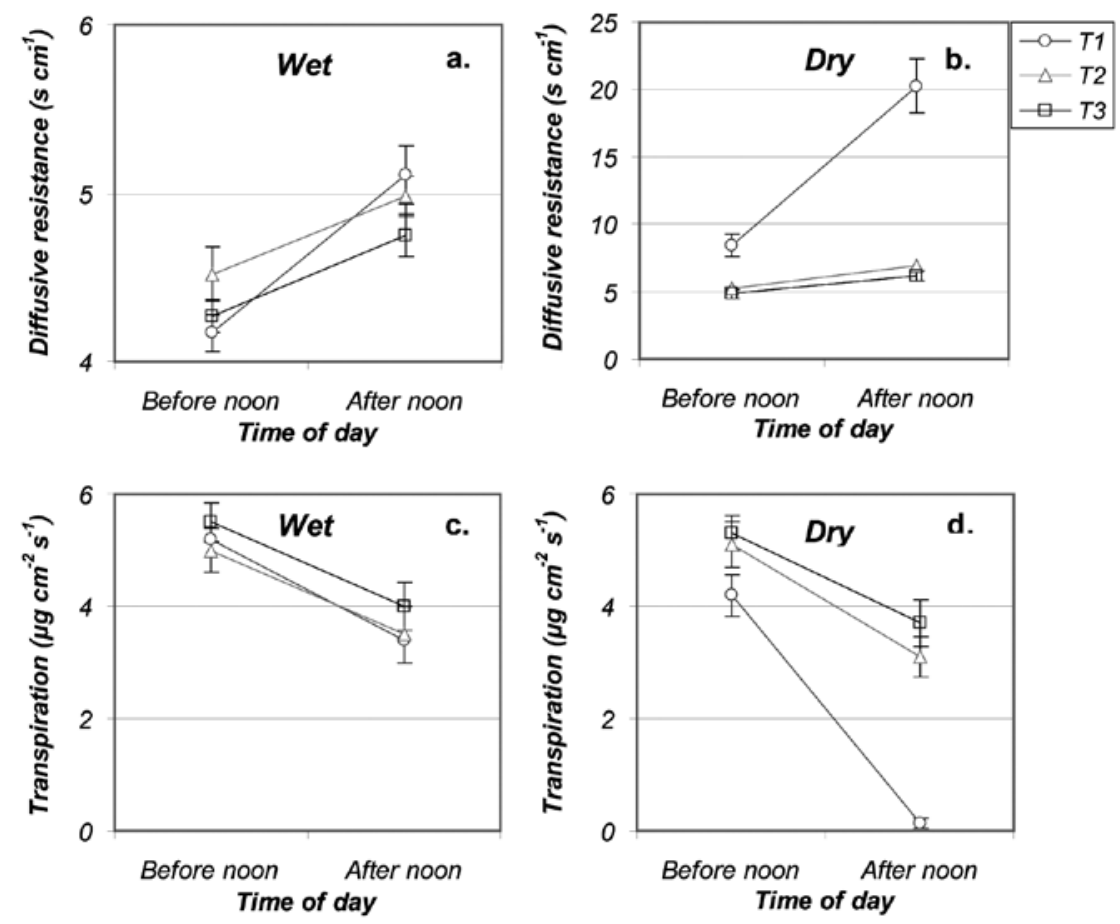

Figure 4: Stomatal diffusive resistance $\left(r_{s}\right)(a \& b)$ and transpiration rate $(E)(c \& d)$ of the $9^{\text {th }}$ leaf from top at different times of the day during wet and dry periods 

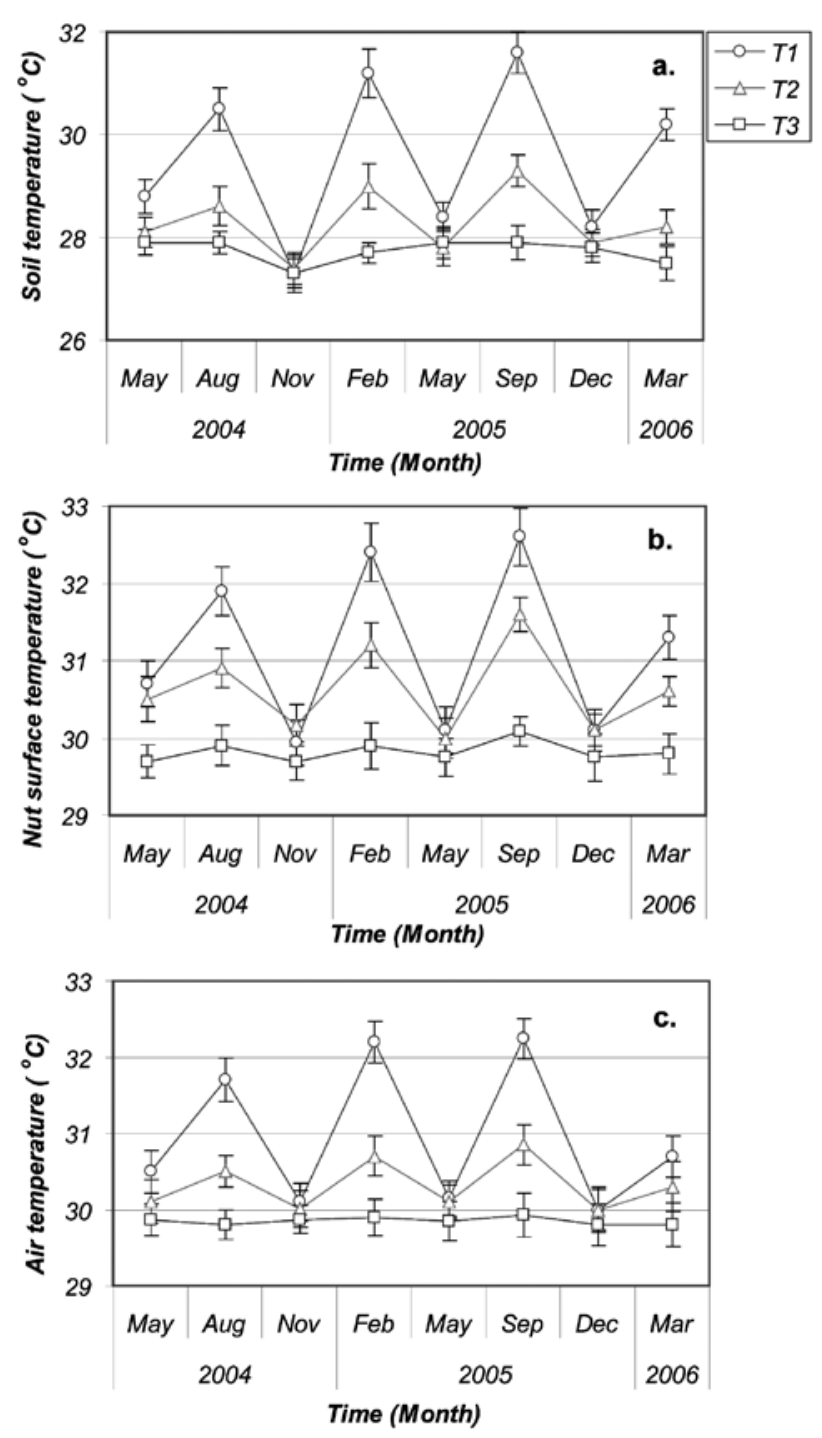

Figure 5: Mean soil temperature $\left(\mathrm{T}_{\text {soil }}{ }^{\circ} \mathrm{C}\right)$ within the top $30 \mathrm{~cm}$ of the soil (a) mean nut surface temperature $\left(\mathrm{T}_{\text {nut }}{ }^{\circ} \mathrm{C}\right)$ of the $7^{\text {th }}$ bunch (b) mean air temperature of the canopy $\left(\mathrm{T}_{\text {air }}{ }^{\circ} \mathrm{C}\right)$ just above the $7^{\text {th }}$ bunch (c) in three treatment plots in the afternoon on each measurement day during the experimental period.
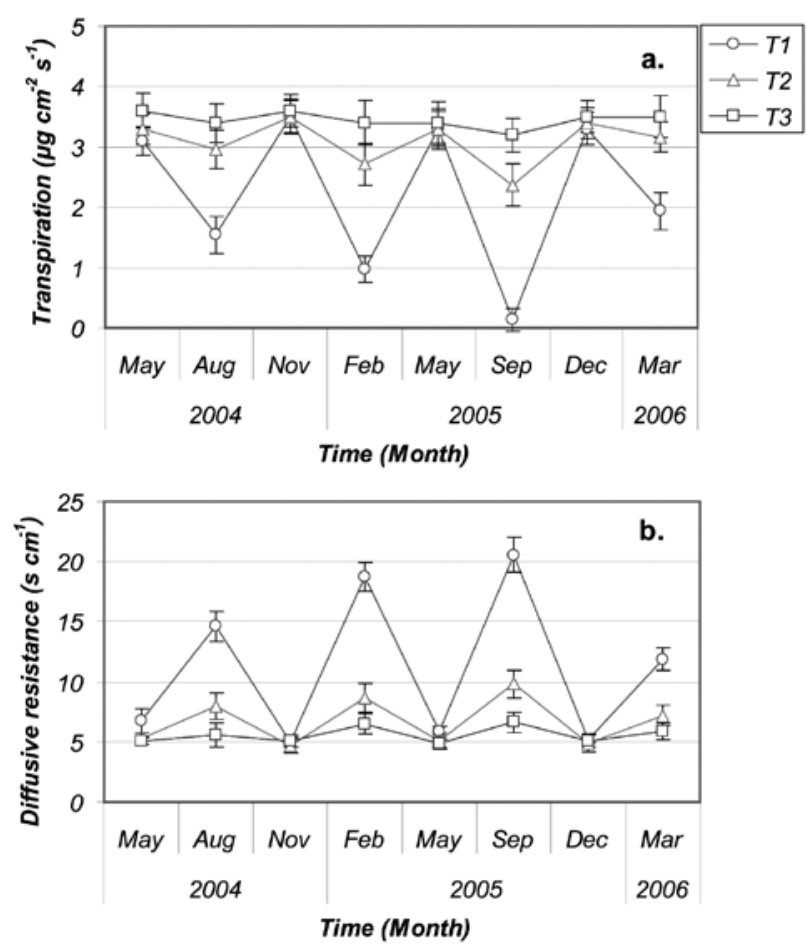

Figure 6: Mean rate of transpiration (E) (a) mean stomatal diffusive resistance $\left(r_{s}\right)(b)$ measured on the $9^{\text {th }}$ leaf from top in three treatments on each measurement day during the experimetal period.

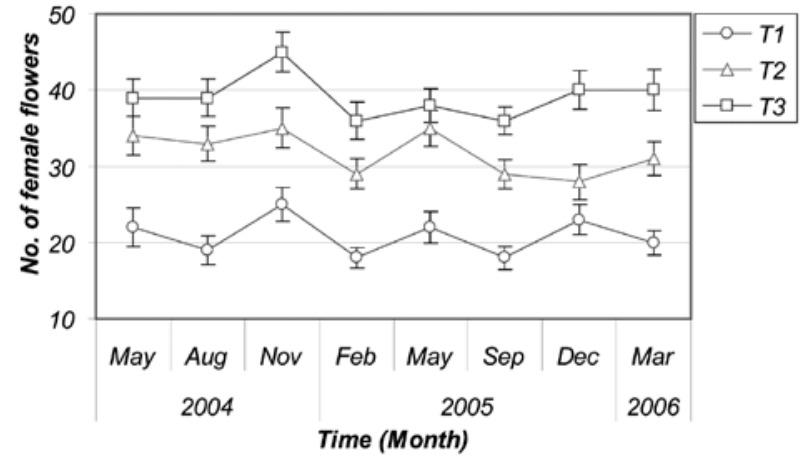

Figure 7: Number of female flowers per inflorescence under different water regimes.

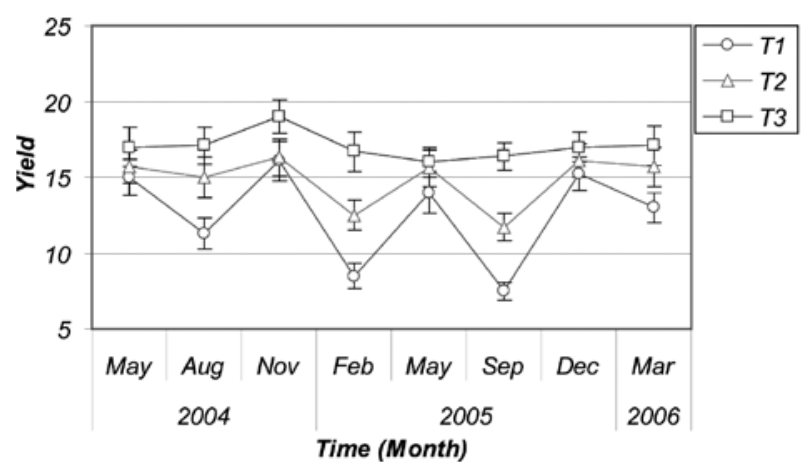

Figure 8: Final coconut yield under different water regimes. 
plots. This indicates a substantial impact of irrigation on maintenance of gas exchange almost uninterrupted even during dry spells. Although no significant difference was observed in both $E$ and $\mathrm{r}_{\mathrm{s}}$ between T2 and T3 plots during the first two dry spells, both differed significantly $(p<0.01)$ in the third and the longest dry spell experienced in September 2005.

\section{Impacts of irrigation on button nut production and yield}

The effects of irrigation are reflected in both the number of female flowers produced per inflorescence and the yield. Both irrigated plots showed significantly higher production of female flowers as compared to nonirrigated control plots throughout the experimental period (Figure 7). Palms in T2 and T3 plots showed 52\% and $88 \%$ higher average female flower production within the period monitored. Also, there were significantly higher number of female flowers per inflorescence within each water regime under wet conditions.

There were no significant differences in yield between treatments during wet periods but yields were significantly reduced $(\mathrm{p}<0.001)$ in bunches developed during dry spells in the control plots (Figure 8). Compared to control plots, T3 plots showed respectively $50 \%, 95 \%$ and $120 \%$ higher yields during the three dry spells experienced within the experimental period (August, 2004, February and September 2005). Yields in $\mathrm{T} 2$ plots for the same periods were $30 \%, 45 \%$ and $55 \%$ higher compared to those in control plots. T3 plots showed about $45 \%$ higher overall yield than the control plots during the experimental period while it was about $20 \%$ higher in T2 plots. Irrigation with $80 \mathrm{~L}$ per palm per day (T3) showed an advantage of about $15 \%$ higher yield as compared to plots irrigated with $40 \mathrm{~L}$ per palm per day.

\section{DISCUSSION}

\section{Impacts of irrigation on temperature increases during dry spells}

The coconut palm thrives well in a climate which is neither very hot (beyond $35^{\circ} \mathrm{C}$ ) nor very cold (below $20^{\circ} \mathrm{C}$ ). Hence, temperature has a great influence on the growth and productivity of coconut ${ }^{5}$. The functional air temperature range for coconut is $20-32{ }^{\circ} \mathrm{C}$ with the optimum being $27{ }^{\circ} \mathrm{C}$ for maximum growth and yield ${ }^{5}$. Root functioning is adversely affected when soil temperature increases above $35^{\circ} \mathrm{C}^{5}$. Results of the present study showed that although the mean $\mathrm{T}_{\text {soil }}$ under well rain- fed conditions was around $27{ }^{\circ} \mathrm{C}$, it increased by about $4{ }^{\circ} \mathrm{C}$ in control plots during the longest dry spell when $\theta$ declined to $7.5 \%$. Thus $\mathrm{T}_{\text {soil }}$ reached the temperature of the upper functional limit and this may have affected root functioning adversely in nonirrigated plots. However, irrigation with $40 \mathrm{~L}$ per palm per day reduced the increase in $\mathrm{T}_{\text {soil }}$ substantially and the mean increase was just above $1{ }^{\circ} \mathrm{C}$. Irrigation with $80 \mathrm{~L}$ per palm per day maintained $\mathrm{T}_{\text {soil }}$ between $27.3^{\circ} \mathrm{C}$ and $27.9^{\circ} \mathrm{C}$, which indicates that $\mathrm{T}_{\text {soil }}$ was almost unaffected due to hot weather under drought conditions. Therefore, irrigation at both levels were able to prevent large increases in $T_{\text {soil }}$ which may have facilitated uninterrupted root functioning.

The foliage canopy is the part of a coconut palm which directly intercepts the incoming solar radiation and thus, it is not surprising to observe a substantially higher $\mathrm{T}_{\text {nut }}$ in spite of wind based dissipation of thermal energy. Although $\mathrm{T}_{\text {nut }}$ of the $7^{\text {th }}$ bunch was slightly higher than that of the $10^{\text {th }}$ bunch in the non irrigated control plots, no significant differences were observed in $T_{\text {nut }}$ between the two bunches when the palms were irrigated. It is important to note that the $\mathrm{T}_{\text {nut }}$ of plots irrigated at 40 and $80 \mathrm{~L}$ per palm per day during dry spells were respectively $2-2.5{ }^{\circ} \mathrm{C}$ and $1-1.5{ }^{\circ} \mathrm{C}$ lower than that of control plots. Similarly, the increase in air temperature within the canopy was more than $2^{\circ} \mathrm{C}$ in control plots as compared to that in the wet period while it was less than $1{ }^{\circ} \mathrm{C}$ in $\mathrm{T} 2$ plots and almost negligible in the $\mathrm{T} 3$ plots. Accordingly, irrigation during the dry period had a significant effect in reducing temperature within the canopy micro climate through evaporative heat loss. This is indicated by the reduction of transpiration by about $95 \%$ in control plots, $25 \%$ in T2 plots and almost no decrease in T3 plots at the end of the longest dry spell within the period. Previous studies ${ }^{6}$, also reported a more than $100 \%$ reduction in transpiration rate in fiveyear old coconut palms with concurrent increases in leaf temperature. Therefore, the provision of water at $80 \mathrm{~L}$ per palm per day during the drought created an approximately similar canopy temperature as observed under well rainfed conditions. Palm canopies in control plots where this cooling effect is not substantial, experience heat build up due to lack of efficient dissipation of thermal energy resulting in an increase in canopy temperature. This increase in temperature possibly affects nuts of different developmental stages. It is very likely that nuts of 6-9 month age group, which undergo shell development and hardening, could be seriously affected ${ }^{7}$. High temperature within the canopy environment during extreme dry spells in certain areas of the country ${ }^{7}$ may be one of the causes for the formation of a considerable number of empty nuts, with no liquid endosperm (coconut water) and weakly developed shells or split shells with the intact husk. 


\section{Impacts of irrigation on gaseous exchange}

Stomatal diffusive resistance during dry spells showed average increases of $70 \%$ and $25 \%$ in $\mathrm{T} 2$ and $\mathrm{T} 3$ irrigated plots compared to that in the wet period while control plots showed more than 4-fold average increase. Therefore, increase in $r_{s}$ was substantially higher in nonirrigated control plots as compared to those of irrigated plots. While the rate of transpiration in control plots decreased by $55 \%, 70 \%$ and almost $100 \%$ respectively during the three dry spells, it was almost unaffected in plots irrigated with $80 \mathrm{~L}$ of water per palm per day. The application rate of water in T3 was effective in maintaining an average soil moisture content $(\theta)$ of $17 \%$ during dry periods. The reduction of $\theta$ down to $14 \%$ in T2 plots resulted in a drop of $E$ by about $25 \%$ during the longest dry period. Greater stomatal opening under irrigation even during dry spells probably indicates greater photosynthesis. Previous studies ${ }^{1}$ reported a more than $20 \%$ reduction of dry matter production in palms exposed to a 24 day dry spell, which could be completely arrested by irrigation. Therefore, the impact of a drought on photosynthesis and dry matter production may be substantially minimized by irrigation.

\section{Impacts of irrigation on button nut production, nut setting and yield}

There were significant differences in the number of female flowers per inflorescence developed during wet and dry periods especially in T1 and also with T2 and T3 to a certain extent (Figure 7). The correlation coefficients (r) of $0.96,0.54$ and 0.75 between $\theta$ and the number of female flowers in $\mathrm{T} 1, \mathrm{~T} 2$ and $\mathrm{T} 3$ water regimes respectively indicated that the conditions prevailing at the time of anthesis exerts an influence on determining the number of female flowers per inflorescence. Earlier reports of the 32 month non-visual development cycle of the inflorescence from flower primodia initiation up to inflorescence opening have shown the influence of conditions prior to anthesis in determining the number of female flowers per inflorescence ${ }^{8,9}$. The results of the present experiment showed that not only the environmental conditions prior to flower opening but also the conditions at the time of anthesis have some influence on the female flower development. As a consequence of the intermittent droughts from 2002 to 2004 period, the number of female flowers was low in non irrigated control palms. On the other hand, irrigated palms which received more or less an uninterrupted water supply during both wet and dry periods prior to the present experiment, developed higher numbers of female flowers. Moreover, nut setting and final yield were directly affected by the microclimatic conditions at the time of flower opening. According to Liyanage ${ }^{9}$, environmental conditions during the first 3-4 months of the year long visual cycle after flower opening is very critical for nut setting. About $50-70 \%$ of immature button nuts would fall-off during this period even under well rain-fed conditions. However, the button nut shedding was just above $40 \%$ in T3 plots irrigated at $80 \mathrm{~L}$ per palm day. Therefore, drought during this highly sensitive period may cause much heavier fall of immature nuts. This situation is reflected in control palms with more than $50 \%$ reduction in set nuts during dry periods when compared with the wet period. Therefore, under irrigation condition the reduction in the number of set nuts was substantially low during most periods. The supply of water during the dry spell could prevent the formation of the abscission layer which precedes button nut shedding ${ }^{10}$. Moreover, irrigation during dry periods could prevent the drying of nectar on the stigma in receptive button nuts. The cooler canopy microclimate could facilitate the pollination process and thereby improve nut setting ${ }^{5}$.

\section{CONCLUSION}

Irrigation has a definite positive impact on lowering the canopy temperature. This reduces the nut surface temperature which is likely to prevent any obstruction to the shell development and thereby reduce the formation of empty nuts during dry spells. Irrigation also reduces the stomatal resistance and may facilitate gaseous exchange through stomata. This in turn would reduce the effects of drought on photosynthesis and improve yield. Irrigation increases the production of female flowers and reduces excessive immature nut fall during droughts. Irrigation with $80 \mathrm{~L}$ per palm per day during drought when compared to $40 \mathrm{~L}$ per palm per day has a greater capacity of lowering the canopy temperature and results in substantial benefits in the improvement of female flower production and nut setting.

\section{Acknowledgement}

Authors wish to extend their sincere thanks to the Coconut Research Board for funding the research work and senior technical officers Mr. R D N Premasiri and Mr. L. R. S. Silva and the divisional staff of the Plant Physiology Division, CRISL for their untiring support for the collection of data continuously for almost a 2 year period. Thanks are also due to Mr. M. A. D. Perera and Mr. K. R. E. M. Fernando, senior field assistants from Soils and Plant Nutrition Division, CRISL for the maintenance and the regular monitoring of the drip irrigation system. 


\section{References}

1. Kasturi Bai K.V. \& Rajagopal V. (1999). Impact of drought on nut yield. In: Advances in Plant Physiology and Biochemistry of Coconut Palm, (Eds. V. Rajagopal \& A. Ramadasan) pp. 79-85. Asian and Pacific Coconut Community, Jakarta, Indonesia.

2. Abeywardena V. (1968). Forecasting coconut crops using rainfall data. Session III of the FAO Technical working party on coconut production and processing, Jakarta, Indonesia. PLCNP/68/29.

3. Nelliat E.V.\& Padmaja P.K. (1978). Irrigation requirement of coconut and response to levels of fertilizer under irrigated condition during the early bearing stage. In: Proceedings of PLACROSYM-1 (Ed. E. V. Nelliat) pp. 186-199. Kasargod, India.

4. Somasiri L.L.W., Nadarajah N., Amarasinghe L. \& Gunathilake H.A.J. (1994). Land suitability assessment of coconut growing areas in the coconut triangle. Coconut
Research Institute, Lunuwila.

5. Mandal R.C. (1998). Coconut-Production and Protection Technology. Agro Botanica, Vyas Nagar, India.

6. Repellin A., Daniel C. \& Zuily-Fodil Y. (1994). Merits of physiological tests for characterizing the performance of different coconut varieties subjected to drought. Oleagineux 49: 155-169.

7 Ranasinghe C.S., Nainanayake A., Gunawardena M., de Saram P.S.A. \& Jayathilake A. (2003). Report of the Plant Physiology Division In: Report for 2003 (Eds. C. Jayasekara, J.M.D.T. Everard, P.A.H.N. Appuhamy \& I.M.S.K. Idirisinghe) pp. 181-183, Coconut Research Institute, Lunuwila.

8. Menon K.P.V. \& Pandalai K.M. (1958). The coconut A monograph. Indian Central Coconut Committee, India.

9. Liyanage M. de S. (1999). A guide to scientific cultivation and management of coconut. Hitech Prints, Nugegoda.

10. Taiz L. \& Zeiger E. (1998). Plant Physiology. Sinauer Associates Inc., Massachusetts, USA. 